\title{
EVOLUTION OF US POLICY TOWARD IRAN'S NUCLEAR PROGRAM IN XXI CENTURY: FROM PRESIDENT BUSH TO PRESIDENT TRUMP
}

\section{ЕВОЛЮЦІЯ ПОЛІТИКИ США ДО ЯДЕРНОЇ ПРОГРАМИ ІРАНУ У ХХІ СТОЛІТТІ: ВІД БУША ДО ТРАМПА}

\section{ЭВОЛЮЦИЯ ПОЛИТИКИ США В ОТНОШЕНИИ ЯДЕРНОЙ ПРОГРАММЫ ИРАНА В ХХІ ВЕКЕ: ОТ БУША К ТРАМПУ}

\section{Sinovets P.}

$\mathrm{PhD}$ in political science, Associate Professor at Department of International Relations, Odessa I. I. Mechnikov National University, Head of OdCNP. E-mail: polina.sinovets@ gmail.com

\section{Gergiieva V.}

PhD student, International Relations Department, Odessa I. I. Mechnikov National University; Junior Research Fellow, Odessa Center for Nonproliferation. E-mail: gergiieva17@gmail.com

\section{Сіновець П.}

Кандидат політичних наук, доцент кафедри міжнародних відносин Одеського національного університету імені I. I. Мечникова, керівник Одеського Центру з питань нерозповсюдження. E-mail: polina.sinovets@gmail.com

\section{Гергісва B.}

Аспірантка кафедри міжнародних відносин Одеського національного університету ім. I. I. Мечникова; молодший науковий співробітник Одеського центру 3 питань нерозповсюдження. E-mail: gergiieva17@gmail.com

\section{Синовец П.}

Кандидат политических наук, доцент кафедры международных отношений Одесского национального университета имени И. И. Мечникова, руководитель Одесского Центра по вопросам нераспространения. Е-таil: polina.sinovets@gmail.com

\section{Гергиева В.}

Аспирантка кафедры международных отношений Одесского национального университета им. И. И. Мечникова; младший научный сотрудник Одесского центра по вопросам нераспространения. E-mail:gergiieva17@gmail.com

Abstract: Since 2002 until now, the Iranian nuclear program remains one of the hottest international problems despite the efforts of three US presidential administrations, which ruled during this time to solve the Iranian issue. This article analyses and compares the policy toward Iran of three US presidents George Bush, Barack Obama, and Donald Trump, discusses the positive and negative consequences of their attempts to solve the Iranian nuclear issue, and outlines the future prospects of US-Iran communication over the nuclear deal. President Trump's policy on Iran was somewhat similar to that of President Bush, both presidents rejected the policy of any concessions to Iran and focused on the policy of pressure. The US withdrawal from the JCPOA influenced not only the relations between the US and Iran, but also the relations of European countries, as since its release in 2018, Europe has tried to save the JCPOA and deter Iran from resuming its nuclear program. In general, Trump's policies not only canceled the nuclear deal, which was the result of long negotiations by the Obama administration, but also complicated further negotiations with Iran. Despite the victory of Democrat Joe Biden, who is a follower of Obama's policies, signing a new agreement with Iran may be even more difficult than it was in 2013-2015, because Iran's missile program has become even more developed, as well as distrust of international treaties as well. The article analyzes the possible consequences of Trump's policies and options for returning to dialogue and agreement. The next crucial stage in Iran-US relations is 
the upcoming elections in Iran in 2021, the results of which will affect the readiness of any concessions to ease sanctions and establish a dialogue.

Key words: Iranian nuclear program, Joint Comprehensive Plan of Action (JCPOA), Nonproliferation Treaty (NPT), economic sanctions.

Анотація: 32002 року іранська ядерна програма залишається однією з найгарячіших міжнародних проблем, попри зусилля трьох адміністрацій президента США розв'язати іранське питання. У статті аналізується та порівнюється політика президентів Джорджа Буша, Барака Обами та Дональда Трампа щуодо Ірану, обговорюються позитивні та негативні наслідки їхніх спроб розв'язати іранське ядерне питання та висвітлюються майбутні перспективи спілкування США та Ірану щзоо ядерної угоди. Так як політика президента Трампа щцодо Ірану була дещьо схожою з політикою президента Д. Буша, обидва президенти відкинули політику будь-яких поступок Ірану та зосередилися на політииі тиску. Вихід США з СВПД вплинув не тільки на відносини США та Ірану, а також на взаємовідносини європейських країн, адже з часу виходу у 2018 році Європа намагалася врятувати СВПД та стримати Іран від відновлення своєї ядерної програми. Взагалі політика Д. Трампа не тільки перекреслила ядерну угоду, яка стала результатом тривалих переговорів адміністраиії Обами, а ще й ускладнила подальші переговори з Іраном. Попри перемогу демократа Джозефа Байдена, який є послідовником політики Б.Обами, підписання нової угоди з Іраном може бути ще складнішим. ніж ие було у 2013 - 2015 роках, адже ракетна програма Ірану розвивалась, а недовіра до міжнародних договорів зростала. $У$ статті проаналізовані можливі наслідки політики адміністращії Д.Трампа та варіанти повернення до діалогу та угоди. Наступний вирімальний етап в ірано-американських відносинах - ие майбутні вибори в Ірані у 2021р., результати яких можуть вплинути на готовність Тегерану йти на поступки заради послаблення санкиій та налагодження діалогу.

Ключові слова: іранська ядерна програма, Спільний всеосяжний план дій (СВПД), Договір про нерозповсюдження ядерної зброї (ДНЯЗ), економічні санкції.

Аннотация: C 2002 года иранская ядерная программа остается одной из самых острых международных проблем, несмотря на усилия трех администрачий президента США, которые правили в то время. В статье анализируется и сравнивается политика президентов Джорджа Буша, Барака Обамь и Дональда Трампа относительно Ирана, обсуждаются положительные и отрицательные последствия их попыток решить иранскую ядерную проблему, а также очерчиваются будущие перспективы американоиранского взаимодействия по ядерной сделке. Так, как политика президента Д. Трампа по Ирану была несколько схожей с политикой президента Д. Буша, оба президента отвергли политику любых уступок Ирана и сосредоточились на политике давления. Выход США из СВПД повлиял не только на отношения США и Ирана, а также на взаимоотношения европейских стран, ведь с момента выхода в 2018 г., Европа пыталась спасти СВПД и сдержать Иран от восстановления своей ядерной программы. Вообще политика Д. Трампа не только перечеркнула ядерное соглашение, которое стало результатом долгих переговоров администрачии Б. Обамы, но и усложнила дальнейшие переговоры с Ираном. Несмотря на победу демократа Джозефа Байдена, который является последователем политики Б. Обамы, подписание нового соглашения с Ираном может быть еще сложнее, чем это было в 2013 - 2015 годах, ведь ракетная программа Ирана стала еще более развитой, как и недоверие $\kappa$ международным договорам также. $B$ статье проанализированы возможные последствия политики администрации Д. Трампа и варианты возвращения $\kappa$ диалогу и соглашения. Следующий решающий этап в ираноамериканских отношениях - это будущче выборы в Иране в 20212., результаты которых когут повлияють на готовность Тегерана идти на уступки ради ослабления санкций и налаживания диалога. 
Ключевые слова: иранская ядерная программа, Совместный всеобъемлющий план действий (СВПД), Договор о нераспространении ядерного оружия (ДНЯО), экономические санкции.

\section{Introduction}

Since the beginning of 21 st century, the Iranian nuclear program has been an international security problem. Three US presidential administrations ruled during this period, and each of them had a particular influence on the Iranian nuclear policy. Interestingly, during all this time the actual leader of Iran, ayatollah Ali Khamenei did not change. However, three Iranian presidents (Mohammed Khatami, Mahmud Ahmadinejad, and Hassan Rouhani), who actually were heads of governments, ruled during the first two decades of the 21 st century, and each of them also influenced the Iranian nuclear policy and US-Iranian relations.

The objective of this article is to consider the evolution of the US policy toward the Iranian nuclear problem since the beginning of 21 st century until now.

Even before the new century began, in 1990-s, the international community had already suspected that Iran was trying to obtain nuclear weapons. There were suspicions that Iran could get sensitive nuclear and technologies from countries like Russia, Pakistan, and North Korea. In addition, in 1990s Iran was considered as one of the US adversaries. As a result, in 1994 the Bill Clinton's presidential administration adopted the doctrine of dual containment of two main US rivals on the Middle East - Iraq and Iran [1].

However, at the beginning of the 21st century, the perception of Iran like a threat significantly increased in the United States. In 2002, some of the Iranian opposition leaders provided information about Iranian successes in developing the nuclear weapons program. As a result, the George Bush administration included Iran together with Iraq and North Korea to the so called "axis of evil". That meant Iran was considered as one of the three most dangerous US adversaries.

\section{The George Bush Administration}

For the United States, the early 2000s were a complicated period of time. That was a time of a shock after 11/9, starting the wars in Afghanistan and Iraq, and growing concerns about the Iranian nuclear program. Perhaps, for those reasons the Bush administration considered Iran as a bigger threat than it actually was.

In fact, in the early 2000s there was a unique opportunity to reach a good nuclear deal with Iran. Until 2005, the moderate reformist politician Mohammed Khatami was an Iranian president. This leader represented those Iranian political forces who were interested in good relations with the West and free trade with other countries. President Khatami proclaimed in his speeches the idea of the dialogue between civilizations meaning the Western and Islamic worlds [2].

Also in 2003, after Iran watched the crushing end of the Saddam Hussein's regime in Iraq, the Iranian leaders expressed their interest to improve relations with the United States, most likely to avoid Iraq's fate. For similar reasons, another leader of the Middle East country, Muammar Qaddafi, voluntarily dismantled Libyan weapons of mass destruction (WMD) program. It is often supposed that Qaddafi was afraid that the United States would also attack his country like they did in Iraq if he did not reject the WMD activities, although the Libyans themselves tried to avoid this impression. [3] It looks like the Iranian leaders had the similar concerns, and to avoid US attack, Iran changed its nuclear policy tactic (although the strategic goals of this policy could remain the same) [4].

In 2003, Iran signed the Nonproliferation Treaty Additional Protocol (NPT AP) which allowed to the inspectors from the International Atomic Energy Agency (IAEA) free access to all the facilities and sites of the country, which could be related to the nuclear activities. In addition, Iran voluntarily suspended uranium enrichment and in such a way removed another concern about its nuclear activities. Between 2003 and 2005, Iran kept its most sensitive nuclear activities frozen, and during that time, Iran also tried to reach a nuclear deal with the United States. According to the former US Secretary of State John Kerry, in 2003 Iran sent a message to the White House 
signalizing its readiness to limit the nuclear program and even recognize Israel and stop supporting paramilitary groups in Syria, Lebanon and Iraq [5].

However, the United States did not use that situation to limit Iranian nuclear activities. Similarly, to later demands of the Trump administration, President Bush expected that Iran would completely eliminate its sensitive nuclear activities like uranium enrichment. Perhaps, at that time the United States thought Iran was weak and it was possible to demand maximum concessions. However, Iran insisted on its right to enrich uranium at least at a limited number of centrifuges. It appears that for Iran, keeping an ability to enrich uranium was a matter of national prestige rather than nuclear weapons issue. Actually, at that time Iran had only 164 primitive centrifuges, [5] and on such a small number it would take many years to enrich enough uranium to produce one nuclear bomb. It appears that the Bush administration missed the unique opportunity to fix the Iranian enrichment possibilities at that limit which would allow Iran just to maintain research activities and consider itself like a modern country with advanced technologies, but in fact would not provide to Tehran any practical possibility to go nuclear. However, the Bush administration did not want to tolerate even less than 200 Iranian enrichment centrifuges. A decade later, during negotiations over the nuclear deal with Iran, the Obama administration had to accept keeping by Iran of thousands centrifuges.

Bush administration's tough policy toward Iran influenced the political situation in this country. The positions of moderate politicians from so called reformist camp in Iran significantly weakened, because their leader president Mohammed Khatami failed to establish good relations with the western countries and improve Iranian economy. The growing skepticism toward US policy in Iran led to increasing popularity of hardliner conservative politicians who supported confrontation with the West and militarization of economy. The Iranian Supreme Leader ayatollah Khamenei, who during more than 30 years of his ruling maneuvered between different camps of Iranian politicians, decided to support hardliners in 2005. As a result, during presidential elections in 2005, a conservative politician Mahmud Ahmadinejad won and became next Iranian president [6].Since that time, Iran stopped trying to negotiate with the United States. Tough policy of Bush administration found a tough response in Tehran. In 2006, Iran suspended fulfilling the NPT Additional Protocol (Iran signed this Protocol in 2003, but never ratified. However, depending on its relations with the West, Iran voluntarily fulfilled Additional Protocol (AP) during some periods of time or suspended its participation in AP). Moreover, since 8 August 2005 Iran resumed uranium enrichment at its facility in Isfahan, and in 2006 started producing new centrifuges [7]. As a result, in few years Iran approached rather close to the nuclear threshold.

The Bush administration tried to stop Iran's nuclear program by economic pressure. In 2006 - 2009, Washington persuaded some oil companies from Western Europe to stop selling necessary equipment to Iran. However, the Bush administration failed to do the same with companies from Eastern Europe (especially from Romania, Hungary, and Belarus) and the Far East [8].

Also there were speculations about the possible military campaign against Iran, and president Bush confirmed later in his memoirs that his administration studied the options to attack Iran [9]. However, the officials in Washington finally understood that the third war at the same time (alongside with military campaigns in Iraq and Afghanistan) would cost too much human lives and money. In addition, the hypothetical war with Iran would be much more difficult than the wars in Iraq and Afghanistan because Iran had much stronger army. Also it would be difficult to destroy the Iranian nuclear infrastructure because most of the nuclear facilities were hidden under the ground in the mountains. The ground military operation in Iran would be also extremely difficult due to complicated climate conditions, rugged relief and numerous mountains in this country. Finally, during the potential war Iran could destabilize the entire Middle East region using its influence on the Shia population in Saudi Arabia, Bahrain, Iraq, United Arabic Emirates and other countries [10].

Thus, the Bush administration avoided catastrophic mistake and did not start the war with Iran. President Bush tried to concentrate on economic sanctions against Iran but not very 
successfully because many other countries did not support those sanctions. The United Nations Security Council (UN SC) [11] and the International Atomic Energy Agency (IAEA) [12] adopted several resolutions which condemned the Iranian nuclear activities and prohibited delivery of the sensitive nuclear and missile technologies to Iran. Nevertheless, the strict international economic sanctions had not been imposed on Iran in 2000s.

Thus, the Bush administration's policy toward Iran was not very effective in general. Nevertheless, starting war in Iraq had some positive nonproliferation effect because Libya and Iran limited their nuclear programs because of fear to be attacked next. However, the final outcomes of Bush policy toward Iran were not successful. Perhaps, the Bush administration expected from Iran the same concessions like from Libya, which completely dismantled and revealed its entire WMD program. However, President Bush seemed to underestimate the Iranian regime, which was stronger and more resilient than the Libyan one. In 2003 - 2005, Iran was ready to make concessions but it insisted on its right to keep at least limited enrichment capabilities. The Bush administration did not accept that Iranian demand, and as a result, the second presidential term of George Bush in 2005 - 2009 did not bring any success in the policy toward Iran. The peaceful negotiations with Iran in P5+1 format (five permanent members of UN Security Council plus Germany) did not bring any results during 2005 - 2013. Iran continued to increase its enrichment capabilities, approach nuclear threshold, develop missile technologies, and Washington could do nothing. The Bush administration could not stop the Iranian nuclear program by the military tools because it was too risky, and it was not possible to influence Iran by economic sanctions too, because even European countries continued to develop economic relations with Iran.

\section{The Barack Obama Administration}

The next president Barack Obama continued the Iran policy of his predecessor at the beginning of his term. However, president Obama refused from any plans to start war against Iran and concentrated on economic sanctions and attempts to negotiate with Iran. Initially Iran refused from making concessions during negotiations like it did during the Bush presidency, so the Obama administration had to focus on sanctions. Obama's sanction policy was more successful than the pressure policy of his predecessor, but the reason was in Iran's tough position during negotiations. Iran continued producing more and more enriched uranium, testing better missiles and refusing from any international proposals to limit its nuclear activities and prove their peaceful aims. For example, in 2006 Iran rejected a Russian proposal to enrich Iranian uranium on the Russian territory and even threatened to leave NPT after its nuclear issue was reported to the UN Security Council [13].

The international community finally understood that the Iranian nuclear and missile program could be a real danger. As a result, in 2010 the UN Security council adopted resolution 1929, which imposed international economic sanctions against Iran [14].

However, these economic sanctions were rather mild because China and Russia usually supported Iran and maintained good relations with it even despite the international pressure. It was a big success that China and Russia did not veto UN SC resolution 1929 and accepted at least limited sanctions against Iran. Also the Obama administration managed to convince the Russian president Dmitry Medvedev not to sell the rocket systems S-300 to Iran in 2010 [15]. In 2009, Russia also stopped cooperation with Iran on space and missile technologies.

Nevertheless, the limited UN Security Council sanctions seemed not to influence Iran. The negotiations between P5+1 and Iran always led to the deadlock or often did not take place at all. In this situation, the Obama administration tried to impose stricter economic sanctions on Iran. Many countries did not support those sanctions, but Obama administration managed to persuade European countries to join the Iranian oil embargo and other strict sanctions which seriously damaged the Iranian economy starting from 2012 [16].

There were skeptical assessments of the sanctions effect on the Iranian economy. However, the Obama administration demonstrated strategic patience, and after several years of economic pressure on Iran, the sanction policy finally brought positive results. The success of this policy was also possible because of the peculiarities of the Iranian strategic culture. The Iranian people were 
ready to protect their independence if necessary, but obviously they were not ready to "eat grass and leaves" to produce nuclear weapons like Pakistan was ready to do according to the 1965 statement of its Prime Minister Zulficar Ali Bhutto [17]. In addition, Iran was not ready to survive under conditions of total isolation like North Korea did. Actually, it is not evident that Iran really wanted to go nuclear like Pakistan or North Korea did. The US National Intelligence Communities published in 2007 the report, which stated that Iran stopped working on nuclear bomb's design in 2003 and since then did not try producing nuclear weapon [18]. Iran focused its nuclear activities on accumulating enriched uranium and plutonium, which could be used for producing the nuclear bomb. However, it is not clear whether Iran really wanted to go nuclear after 2003 or it just developed enrichment technologies to increase its national prestige and distract public attention from economic problems. Perhaps, the hardliner president Mahmud Ahmadinejad with his supporters and probably some radical elements in the paramilitary organization Islamic Revolutionary Guards Corp (IRGC) really wanted to obtain nuclear weapons and for that reason chose a confrontation approach toward relations with the West. However, it seems that in a complicated Iranian political structure many influential figures opposed the attempts to obtain nuclear weapons. It appears that after the hardliner president Mahmud Ahmadinejad left the office in 2013, the final goal of the Iranian nuclear program was just increasing national prestige and using its achievements as a bargaining tool in negotiations with the West.

In 2013, the second presidential term of Mahmud Ahmadinejad ended, and he had to leave the office. It was expected that another, more loyal to the Supreme Leader person from the hardliners camp, would become the new president in 2013 [19].However, the elections were surprisingly won by the moderate politician Hassan Roukhani. Nevertheless, his victory appears to be reasonable and most likely, it became possible due to the Obama administration's policy of pressure on Iran. The regime had already experienced massive unrest after the previous presidential elections in 2009, when Mahmud Ahmadinjad officially won, but many people protested against this election result because they were unsatisfied with ineffective economic policy and growing isolation of Iran. Thus, would another hardliner win the election in 2013, the social unrest could be even more catastrophic than four years before. Therefore, for the Supreme Leader and his supporters, it was better simply to organize fair elections in order not to provoke another unrest and instability. The new president Hassan Roukhani was also rather loyal to the Supreme Leader and did not want to change radically the Iranian political system. However, in contrary to hardliner most loyal supporters of ayatollah Khamenei, he and other representatives from moderate reformist camp wanted to improve relations with the West, remove economic sanctions and develop free market economy in Iran. In 2013, the Supreme Leader had to recognize that such policy would be more rational than continuing confrontation because the Iranian economy was in a very bad position after US and European embargo of the Iranian oil. In addition, Iran had to spend many costs to support his ally president Bashar Assad in Syria and urgently needed currency for projecting its influence abroad. Thus, ayatollah Khamenei allowed president Roukhani and his team to start negotiations with the West.

These negotiations were not easy but successful. In November 2013, Iran and P5+1 countries signed an interim nuclear deal, and in July 2015 they signed the Joint Comprehensive Plan of Action (JCPOA).It was one of the biggest achievements of President Barak Obama.

Nevertheless, achieving a nuclear deal with Iran had some positive consequences. First of all, for the first time since the Islamic Revolution in 1979 and capture of American diplomats in Tehran, Iran and the United States achieved positive results after negotiations. Although both countries still did not reestablish diplomatic relations, presidents Roukhani and Obama had a phone conversation [20], and even that was a historic achievement. Furthermore, before signing the JCPOA, the Iranian nuclear program issue had remained unresolved during decades and it was hard to believe that that issue would be ever settled because often it was difficult even to arrange a meeting with the Iranian negotiators, not to say about achieving any progress during negotiations. However, due to the efforts of Obama administration, the historic deal with Iran was done. Moreover, Iran strictly followed all the provisions of the deal [21], which significantly reduced the 
Iranian nuclear program. The IAEA inspectors received free access to all the nuclear facilities in Iran and thus, at any time they could watch Iranian nuclear activities. After the numerous inspections, the IAEA always confirmed in its reports that Iran fulfilled JCPOA and did not attempt to produce nuclear weapons [22].

\section{The Donald Trump Administration}

The Trump administration's approach toward Iran is a bit similar to the Bush administration's policy. Both administrations demanded complete dismantlement of the Iranian enrichment capabilities and both of them considered military option to solve the Iranian nuclear issue. President Trump undertook even more radical measures toward Iran than President Bush did: in January 2020 Donald Trump ordered to kill the influential Iranian general Khasem Soleimani. Nevertheless, like president Bush or any other US president, Donald Trump decided not to start the war with Iran even after Iran hit the US military base in Iraq [23].It appears that incident showed the general weakness of Trump's policy toward Iran.

Nevertheless, Trump's approach toward Iran also brought some results. Refusing the military option, the Trump's administration focused on the economic sanctions against Iran. Unlike president Obama, Donald Trump was not able to persuade joining US sanctions even the European allies, but even the unilateral US sanctions significantly curtailed the Iranian economy [24].Perhaps, that was a real goal of the Trump's administration - to reduce the Iranian financial possibilities and hinder Tehran to support pro-Iranian groups in Iraq, Syria and Yemen.

After the United States withdrew from JCPOA in May 2018 and started to impose sanctions on Iran, Tehran waited for a year remaining in the JCPOA. Only in May 2019, Tehran decided to withdraw gradually from JCPOA too. On 6 January 2020 after killing General Soleimani, Iran declared its independence from JCPOA. However, this unlikely means that Iran decided to obtain nuclear weapons. Iran gradually breaks the limitations of JCPOA, but does not undertake any provocative steps. For example, JCPOA allows Iran to enrich uranium until 3,67\% level, and Iran enriches uranium until 4,5\% [26] only which is also rather low level. Assessing some statements of the Iranian officials, it could be expected that after killing General Soleimani Iran would start enriching uranium to $20 \%$, and from this level, it is technically easier to enrich it until weaponsgrade mark of $90 \%$ [26]. However, Iran did not take such provocative steps. It seems like Iran shows that it is still ready to go back to JCPOA if US policy changes. It appears that Iran simply decided to wait until the US presidential elections in November 2020 and then reconsider its nuclear policy taking into account their results.

Assessing the consequences of Trump's policy toward Iran, it should be recognized that despite many weaknesses and mistakes it has a rational logic. JCPOA appears to be a good achievement because it limited the Iranian nuclear program, but that deal was not ideal because Iran remained US adversary, which could get even stronger due to the lifting sanctions. Furthermore, reaching the JCPOA demonstrated that the economic sanctions against Iran worked. Thus, Trump administration decided to check whether economic sanctions would work to get a better deal with Iran.

On the one hand, such a policy of pressure on Iran had negative results because it led to the victory of the hardliner politicians on the parliamentary elections in Iran in February 2020. Similarly, like in 2005, the moderate policymakers who tried to improve relations with the West in 2013 - 2017, caused the public disappointment. In 2005, the reformist president Mohammed Khatami was replaced by conservative Mahmud Ahmadinejad because the Iranian people were disappointed by Khatami's unsuccessful efforts to improve economic situation trying to establish better negotiations with the West [27]. In 2020, the situation was similar: the efforts of reformist president Hassan Roukhani and its government to improve relations with the West did not improve economic situation because the period of lifting sanctions from Iran was too short, and then replaced again by the hard US economic sanctions. Thus, the Iranians experienced twice in their recent history the similar situation: Iranian attempts to negotiate with the United States always ended by the negative response from Washington and renewing pressure even despite the Iranian concessions. This negative experience in both cases led to increasing popularity of the hardliner 
politicians who advocate confrontation with the West and relying on the Iranian military capabilities. Thus, following the hardliners victory at the parliamentarian election in Iran in 2020, it could be expected that another conservative politician would win presidential election in June 2021 [28]. In this case, the further development of the Iranian nuclear program and growing USIran confrontation could be expected which would mean the negative results for Washington.

On the other hand, the Trump's policy of pressure led to weakening the regime in Tehran. In 2017 - 2018 and especially in 2019 - 2020, Iran experienced mass protests against the ruling elite. The US sanctions caused increasing gasoline prices in Iran, and mass protests against this increasing in November 2019proved that the Iranian people were highly unsatisfied with the ayatollahs regime. The usual rotation of the reformists and hardliners in the government and parliament would unlikely satisfy people who called during these protests to remove the Supreme Leader and change the political system completely [29]. In December 2019, the government managed to brutally suppress the mass unrest, but few weeks later, the Iranian people protested again demanding ayatollah Khamenei's resignation after Iran admitted shooting down the Ukrainian plane on January 8, 2020 [30].During next presidential elections another wave of protests seems to be possible.

Trump's adventure with killing General Soleimani led to a temporary increasing popularity of the ruling regime [31]. However, Trump's administration avoided other adventures in Iran, and now the regime's popularity seems to decrease again because the people face again the economic problems in their everyday life, not the aggression of the United States.

President Trump declared in September 2020 he believed that after the US presidential election and his supposed win reaching a "fair" nuclear deal with Iran would be possible [32].

However, it seems that reaching a nuclear deal with Iran would be difficult for any US president after the presidential elections because the current situation looks far more complicated for the negotiations than it was in 2013 - 2015. First of all, the United States and its allies experienced the massive missile strikes from Iran and its proxies, like attacks on the US base in Iraq in January 2020 or the Saudi oil facility in September 2019 [33]. Therefore, it appears that the next US president would unlikely lift economic sanctions from Iran unless it receives the clear guarantees from Iran that such attacks would not take place anymore. Including such guarantees into the new deal with Iran could be a far more complicated issue than the simple reviving the nuclear part of the deal.

Finally, the COVID-19 pandemic may also hurt the prospects of reaching a new deal with Iran after the US presidential elections. Due to the pandemic, the Iranian economy would remain in bad conditions during the nearest time, and lifting economic sanctions would not radically improve the economic situation in Iran. Therefore, even despite the threats of new social unrest the Iranian leaders would unlikely agree to make huge concessions on the nuclear, missile and regional security issues if they receive just sanction relief, like it was in $2013-2015$.

\section{Conclusions}

Comparing the policy of three US presidents (George Bush, Barack Obama, and Donald Trump) toward Iran, the following conclusion could be made: all three presidents used the policy of pressure on Iran, and all of them preferred economic sanctions rather than military options. Barack Obama was most successful in this sanction policy, because he was the only US president who managed to achieve the deal with Iran. However, this deal was strongly criticized by Obama's successor president Trump and his team.

Trump's policy toward Iran was a bit similar to the policy of President George Bush. Both of them rejected concessions to Iran and focused on the policy of pressure. Both of them considered the military option to solve the Iranian nuclear issue and both finally decided not to start the war although president Trump undertook a military adventure with killing Iranian general Soleimani.

However, the consequences of the Trump's policy toward Iran were likely more farreaching and destructive than the results of the Bush policy. Despite the mistakes of the Bush administration, his successor president Obama managed to organize a consolidated and effective 
international economic pressure on Iran and later reach a nuclear deal with Iran. That deal was not ideal, but at least it brought some stability into the region.

By the end of the first presidential term of Donald Trump, that stability had been destroyed, the NATO unity had been significantly damaged, and the United Stated had to deal with Iran alone, even without support of the closest allies. Iran used the weaknesses of Trump's strategy to undertake unprecedented provocative steps in the Middle East region and further advance its space and missile technologies. In response, the Trump administration managed to significantly damage the Iranian economy and increase the risks of social unrests in Iran. However, the pandemic recession could decrease the effectiveness of the US economic pressure on Iran because the Iranian economy like in any other country of the world would suffer even without sanctions, and Iranian people seem to understand that. Thus, achieving a new deal with Iran could be even more complicated after 2020 US presidential elections than it was prior signing the JCPOA in $2013-$ 2015.

Under these difficult conditions, the following recommendation could be suggested. A partial and gradual returning to JCPOA appears to be the best option. For example, until reaching a compromise on regional security or missile issues, Iran, the United States and other P5+1 countries could at least agree that Iran would continue fulfilling NPT Additional Protocol and provide free access for the IAEA inspectors to all its nuclear sites. Also both sides could agree that Iran would not further increase the quantities of its enriched uranium. In return, the United States could oblige not to impose new sanctions on Iran and provide access for Iran at least to part of its frozen assets in the foreign banks. Lifting other economic sanctions and returning to other provisions of the JCPOA (like reducing enriched uranium stockpiles to $300 \mathrm{~kg}$ and fixing uranium enrichment level to $3,67 \%$ etc.) could be postponed to later times, depending on Iran - P5+1 negotiations on the Middle East regional security issues and Iranian missile program. The mutual obligations of the United States and Iran not to attack each other forces could be a good start for the negotiations on the non-nuclear issues.

\section{References:}

1. Gause F. G. III (1994). 'The Illogic of Dual Containment. Foreign Affairs'. March/April, <https://www.foreignaffairs.com/articles/iran/1994-03-01/illogic-dual-containment >.

2. Khatami' P. F. (2004). 'Dialogue among Civilizations as International Political Theory'. J. Humanities Vol. 11 (3): 11-29, <https://eijh.modares.ac.ir/article-27-9945-en.pdf>.

3. Braut-Hegghammer M. (2017). 'Giving Up on the Bomb: Revisiting Libya's Decision to Dismantle its Nuclear Program'. Wilson Center. October 23, <https://www.wilsoncenter.org/blogpost/giving-the-bomb-revisiting-libyas-decision-to-dismantle-its-nuclear-program $>$.

4. The Iraq War's Impact on Nonproliferation. Roundtable Moderated by the Wisconsin Project on Nuclear Arms Control. Panelists: W. Seth Carus, Nicholas Eberstadt, Robert J. Einhorn, Micheal Eisenstadt. Iran Watch. April 14, 2004,<https://www.iranwatch.org/ourpublications/roundtable/iraq-wars-impact-nonproliferation>.

5. Kessler G. (2013). 'Kerry's claim that Iran offered Bush a nuclear deal in 2003'. Washington Post.

Dec.

9,<https://www.washingtonpost.com/news/factchecker/wp/2013/12/09/kerrys-claim-that-iranoffered-bush-a-nuclear-deal-in-2003/ > .

6. Victory for a religious hardliner in Iran. The Economist. 27 June 2005, <https://www.economist.com/news/2005/06/27/victory-for-a-religious-hardliner-in-iran >.

7. Iran's Nuclear Program Timeline and History. NTI. Last Updated: June 2020, <https://www.nti.org/learn/countries/iran/nuclear/ >.

8. Kozhanov A. N. (2011). 'U.S. Economic Sanctions against Iran: Undermined by External Factors'. Middle East Policy Council Journal. Vol. XVIII, Fall, No.3, <https://mepc.org/useconomic-sanctions-against-iran-undermined-external-factors>. 
9. George Bush's memoirs reveal how he considered attacks on Iran and Syria. The Guardian. 8 November 2010 https://www.theguardian.com/world/2010/nov/08/george-bush-memoirdecision-points

10. Mousavian H. (2012). 'Column: Twenty reasons not to attack Iran'. Reuters. 23 August, $<$ https://www.reuters.com/article/us-column-twenty-reasons-iran-idUSBRE87M10I20120823>.

11. IAEA and Iran - UN Security Council Resolutions and Statements. IAEA, <https://www.iaea.org/newscenter/focus/iran/iaea-and-iran-un-security-council-resolutions-andstatements>.

12. Implementation of the NPT Safeguards Agreement in the Islamic Republic of Iran. Resolution adopted on 4 February 2006. IAEA. GOV/2006/14, <https://www.iaea.org/sites/default/files/gov2006-14.pdf >.

13. Iran Rejects Russian Uranium Enrichment Proposal. NTI Analysis. 13 March 2006, <https://www.nti.org/gsn/article/iran-rejects-russian-uranium-enrichment-proposal/>.

14. Resolution 1929 (2010). Adopted by the Security Council at its 6335th meeting, on 9 June 2010. United Nations Security Council, <https://www.undocs.org/S/RES/1929\%20 (2010)>.

15. Kremlin bans sale of S-300 missile systems to Iran. BBC News. 22 September 2010, <https://www.bbc.com/news/world-europe-11388680>.

16. Kitous A., Saveyn B., Gervais S., Wiesenthal T., Soria A. (2013). 'Analysis of the Iran oil embargo'. European Commission. Joint Research Center Scientific and policy reports, <https://publications.jrc.ec.europa.eu/repository/bitstream/JRC77983/lfna25691enn.pdf>.

17. Nandan T. (2012). 'Having the a-bomb and eating grass did Pak no good'. Governance Now. 29 March, <https://www.governancenow.com/news/regular-story/having-bomb-and-eatinggrass-did-pak-no-good $>$.

18. Miller G. (2007). 'Iran halted nuclear push in 2003, U.S. now says'. Los Angeles Times. 4 December, <https://www.latimes.com/archives/la-xpm-2007-dec-04-fg-iran4-story.html>.

19. Iranian presidential elections 2013: the essential guide. The Guardian. 13 May 2013, <https://www.theguardian.com/world/2013/may/13/iranian-presidential-election-2013-iran>.

20. Mason J., Charbonneau L (2013). 'Obama, Iran's Rouhani hold historic phone call'. Reuters. $28 \quad$ September, <https://www.reuters.com/article/us-un-assembly-iranidUSBRE98Q16S20130928>.

21. The Iran Nuclear Deal at Two: A Status Report. International Crisis Group. Report No.181 I MIDDLE EAST \& NORTH AFRICA Washington/Brussels, 16 January 2018, $<$ https://www.crisisgroup.org/middle-east-north-africa/gulf-and-arabian-peninsula/iran/181-irannuclear-deal-two-status-report>.

22. Iran is Implementing Nuclear-related JCPOA Commitments, Director General Amano Tells IAEA Board. IAEA. 5 March 2018, <https://www.iaea.org/newscenter/news/iran-isimplementing-nuclear-related-jcpoa-commitments-director-general-amano-tells-iaea-board>.

23. Iran launches missiles at Iraq airbases hosting US and coalition troops. The Guardian. 8 January 2020, <https://www.theguardian.com/world/2020/jan/08/suleimani-assassination-two-usairbases-in-iraq-hit-by-missiles-in-retaliation>.

24. Six charts that show how hard US sanctions have hit Iran. BBC News. 9 December 2019,<https://www.bbc.com/news/world-middle-east-48119109>

25. Iran enriches uranium to $4.5 \%$, breaking nuclear deal limits. PBS News Hour. 8 July 2019, $<$ https://www.pbs.org/newshour/world/iran-enriches-uranium-to-4-5-further-breaking-nucleardeal-limits $>$.

26. Ritter M. (2019). 'AP explains: Science of uranium enrichment amid Iran tension'. 20 May, <https://apnews.com/article/2117a20bd5a747f2a0956ec7b1ef4264>.

27. Students slam Khatami reform failure. Aljazeera. 6 December 2004, <https://www.aljazeera.com/news/2004/12/06/students-slam-khatami-reform-failure/>.

28. Geranmayeh E. (2020). 'Reviving the revolutionaries: How Trump's maximum pressure is shifting Iran's domestic politics'. European Council on Foreign Relations, 23 June, 
<https://www.ecfr.eu/publications/summary/reviving_the_revolutionaries_how_trumps_maximum _pressure_is_shifting_irans>.

29. Erdbrink T. (2017). 'Iran Confronts 3rd Day of Protests, With Calls for Khamenei to Quit'. The New York Times. 30 December, <https://www.nytimes.com/2017/12/30/world/middleeast/iran-protests-rouhani.html>.

30. Griffith K. (2020). 'Protesters in Tehran clash with riot police as they demand the Ayatollah resigns and call for regime change after Iran finally admits to shooting down jet and killing 176 people'. Daily Mail. 11 January, <https://www.dailymail.co.uk/news/article7876363/Iranian-protesters-Tehran-turn-against-regime-military-admits-shooting->>plane.html> .

31. Rennenkampff M. (2020). 'Killing Soleimani: How Trump united Iran against America'. The Hill. 6 January, <https://thehill.com/opinion/national-security/476919-killing-soleimani-howtrump-united-iran-against-america $>$.

32. Trump on Future Deal with Iran. The Iran Primer. 16 September 2020 <https://iranprimer.usip.org/blog/2020/sep/16/trump-future-deal-iran>.

33. Saudi Arabia oil attacks: Weapons debris 'proves Iran behind them'. BBC News. 18 September 2019, <https://www.bbc.com/news/world-middle-east-49746645>. 